\title{
Land Grabbing And Its Impact On Food Security In Sub-Saharan Africa
}

https://doi.org/10.21272/sec.3(4).72-85.2019

\section{Boutchouang Nghomsi Chanceline}

ORCID: https://orcid.org/0000-0003-2095-0022

Economist, Consultant, B\&M Consulting, Cameroon

\begin{abstract}
Over the last decade, the synergy between the financial and food crises has led to the emergence of new processes in the functioning of national economies - the seizure of agricultural land. On the one hand, the governments of most African countries, for the sake of their food security, import food and buy agricultural land overseas to organize their own agricultural production. On the other hand, the main purpose of multinational companies investing in land purchases is to generate more profit. This situation led to the rapid and complete privatization of agricultural land on the African continent between 2008 and 2010, while the locals were living outside poverty. The peasants' right of access to land is no longer guaranteed, they have remained unprotected in their own territories. At present, exponential population growth and its needs are taking place, access to land and water is a crucial element of government. The purpose of the article is to analyze the probable conflicts in land relations arising from the transfer of land to multinational companies. The term 'land grabbing' means the large-scale acquisition (purchase, lease) of agricultural land by private individuals for commercial purposes abroad and in the long term (30-90 years) for agricultural production or biofuel production for export. The author of the article found that the products grown on these lands will be destined for the population of other countries, which is detrimental to the local population. Consequently, the seizure of land will in the future have negative socio-economic consequences for society: the destruction of farms, the exacerbation of contradictions between the rural population, the destruction of community fields beyond land acquired by foreign states and transnational corporations. In addition, the study concludes that, first, the seizure of land on the African continent through foreign direct investment, capital transfers, technology and job creation can help to increase the individual income and standard of living of the local population, and thus promote food security; secondly, the significant demand for food and biofuels in the world, population pressures and climate change are factors contributing to the improvement of product quality in the African continent.
\end{abstract}

Keywords: land grabbing, food security, impact, rural agriculture, Sub-Saharan Africa.

JEL Classification: Q18, O2.

Cite as: Boutchouang Nghomsi Chanceline (2019). Land Grabbing And Its Impact On Food Security In SubSaharan Africa. SocioEconomic Challenges, 3(4), 72-85. https://doi.org/10.21272/sec.3(4).72-85.2019.

(C) The Author, 2019. This article is published with open access at Sumy State University.

\section{Introduction}

Between late 2007 and early 2008, the world is severely hit by an unprecedented economic and financial crisis and the emergence of agro-fuels that have contributed to rising food prices. This rise in prices was mainly caused by stock market speculation in staple foods and their high volatility. In fact, many agricultural commodities had become a mere commodity that fueled hedge funds and their prices fluctuated with human manipulation (Ziegler, 2011).

As a result, we have seen the onset of several popular riots linked to the growing famine called "hunger riots" that have raged in many parts of the world.

However, we are seeing strong population growth on the continent, putting enormous pressure on the agrifood system, which is thus failing to meet the needs of this population. The food system is at a crossroads; the era of infinity promised by a globalized neoliberal system is at its peak (Severino and Ray, 2011: 78). 
Faced with the increasing liberalization of trade, the scarcity of resources and a growing demand for food and energy, the imbalance of global markets and agrarian economies that exacerbate the pressures on a system already undermined. One thing is clear: the model of agricultural development promoted by neoliberal policies is fragmenting (Potvin, 2013).

To overcome this handicap, several strategies are implemented by the stakeholders. Some opt for investments in agricultural land, relocating food and agrofuel production. We are also witnessing the commodification of the territory and its resources (Potvin, 2013). The frantic race towards arable and agricultural lands is the new panacea for the economic powers, the land resource has become the new eldorado of the main actors of the world economy. This craze completely disrupts the global food system.

The phenomenon is referred to as "land grabbing" which results in the purchase or lease of large areas of land in a foreign country by a third party. It is part of a global context of change in countries such as China, India, Saudi Arabia, Japan, the United States and some European countries aim to ensure their food security. This rush to farmland and natural resources is also motivated by biofuel needs to meet energy security (Mc Michael and Scoones, 2010). Also, in the wake of this financial and mortgage crisis, the financial sector and banks have been interested in arable land as a source of financial return, land is perceived as safe haven, a kind of guarantee on financial investments.

Since then, land use has attracted private investors, governments and hedge funds, presenting new safe investments with positive return potential. It is against this backdrop that crown corporations, private companies and investment funds have opted for international agricultural land trade (Potvin, 2013).

In this new phenomenon of the global economic system, the countries of Africa, particularly the sub-Saharan countries, are the most important targets of land grabbing in the world (Borras, et al., 2012: 845).

On the other hand, these countries in the region are also the most affected by malnutrition, undernourishment and famine (UNDP, 2012: vi). Agriculture is a critical political, economic and environmental issue for the African continent and its development, particularly south of the Sahara (Rigg, 2006). More than 70\% of the population lives in rural areas and the majority rely heavily on agriculture to survive (World Bank, 2013a). The issue of food self-sufficiency, which emerged during the 2008 food price spike, is more critical than ever.

Despite progress, one in three people are chronically undernourished in Sub-Saharan Africa. This region, marked by hunger, also has the highest agricultural potential in the world. It holds nearly $50 \%$ of the world's uncultivated arable land, and uses only $2 \%$ of its renewable water resources (World Bank, 2013). Some booming markets such as rice, corn, soybeans and palm oil can be grown on sub-Saharan lands. Such agricultural development would enable African countries to become one of the major producers and exporters of these commodities. The benefits for African economic development are enormous. But the risks are also important. Foreign direct investment in African lands is a major issue in contemporary agricultural economic development (Potvin, 2013).

Thus noted, we note that the phenomenon of land grabbing exposes the issue of food insecurity in Africa. It will be for us in the development of our article to question the relevance of the impact of the phenomenon of land grabbing in Africa on food insecurity, if it can help to stem it or if it is a threat to food security on the continent.

\section{Concepts and theoretical framework and methodology}

\subsection{Definition of Concepts and their evolution over time}

\subsubsection{Land grabbing}

The term land grabbing (grab grab) has re-emerged on the international scene in the context of the global food price spike in 2007-2008. From this period we witnessed a frantic race for the relatively wild acquisition of vast tracts of agricultural land on the African continent. Between 2008 and 2010, companies and states granted themselves more than 80 million hectares (Land grabbing, denouncing land grabbing, Slow food, 2010), the majority of which in Africa evaluated at almost hundred billion dollars. The World Bank, more cautious, evokes a figure of around fifty (50) billion US dollars.

Below is a table of the countries most affected by the phenomenon of land grabbing. 
Table 1. Countries affected by land grabbing

\begin{tabular}{|c|c|}
\hline Country & Surface (in millions d'ha) \\
\hline Madagascar & 3,7 \\
\hline DRC & 3,2 \\
\hline Tanzania & 2,8 \\
\hline Sudan & 2 \\
\hline Mozambica & 1,6 \\
\hline Benin & 1 \\
\hline Cameroon & 0,7 \\
\hline Kenya & 0,6 \\
\hline Mali & 0,5 \\
\hline
\end{tabular}

Source: Author's calculations.

The land is not all redeemed, there are also long-term leases ranging from 30 to 99 years. The largest countries buying land are presented in table 2 .

Table 2. Countries owners of land

\begin{tabular}{|c|c|}
\hline Country & Surface (in millions d'ha) \\
\hline China & 4,5 \\
\hline USA & 3,2 \\
\hline Malaisia & 2,5 \\
\hline Great Britain & 2,5 \\
\hline South Corea & 2,3 \\
\hline Saoudy Arabia & 2,1 \\
\hline India & 1,8 \\
\hline Sweden & 1,1 \\
\hline South Africa & 0,9 \\
\hline
\end{tabular}

Source: Author's calculations.

However, it is important to emphasize that massive land acquisition in developing countries is not a new phenomenon, since it was widely practiced during colonial and postcolonial imperialist conquests (Tayler and Bending, 2009, Songwe and Deininger, 2009).

For Moyo (2012: 13), land grabbing in Sub-Saharan Africa is part of a historical process in which land alienation, land accumulation strategies and dispossession of peasants have deconstructed African food production systems and redefined the agrarian productive forces. Similarly, for Ingwe, Ikeki and Ojong (2010), the resurgence of this land race in Africa is largely due to the legacy of weak governance resulting from neoliberal policies and colonialism.

In a context marked by the increasing concentration of land and the diversification of forms of agricultural production on a large scale, the contemporary phenomenon of land grabbing is, according to Moyo (2012: 20), a third wave of acquisition of agricultural land by strangers. For the author, the first wave of land grabbing is in the colonial period of Africa, while the second wave refers to the nationalization of agricultural land following the independence of the colonies. Moyo (2012) explains that at that time, the agricultural elite nationalized the land in order to increase exports. Land grabbing in Sub-Saharan Africa, in its current wave, raises fundamental issues, including the concentration of land in the hands of a few foreign actors and the growing marginalization of peasants and their traditional practices in favor of industrial practices and practices. capitalist modes of production (Bernstein, 2002). Essentially,

The rapid increase in the commodification of land, or the globalization of agriculture and its market value, encourages an "accumulation by the top on a socially narrow and geographically narrow basis" (Moyo, 2012: 17). According to this premise, land grabbing in Sub-Saharan Africa, if one wants to understand its complexity and nature, must first be analyzed as a socially constructed process that builds on a series of neoliberal regimes of occupation and control over land. land, and secondly be observed according to their political, socioeconomic and agroecological trajectory. This is precisely what agrarian political economy allows us. At present, the "land-grabbing" model (Harvey, 2003) of African land ownership continues to be inspired by an outward-oriented agricultural strategy, undermining domestic agricultural production structures and the role of different classes. agrarian (Moyo, 2010: 181). The emphasis is therefore on the international or "foreign" 
character of land grabbing. For Moyo (2012: p22), land grabbing in Sub-Saharan Africa clearly illustrates the structural distortion of the agrarian system.

Land concessions are now at the heart of fierce controversy. For many observers, land grabbing has become a major development issue (Zoomers, 2010: 429). Foreign direct investment in the land sector is burgeoning, generating both opportunities for development, but also problems and risks (Cotula et al., 2009, Taylor and Banding, 2009, von Braun and Meizen-Dick , 2009). Opinions are divided on agricultural investments and their benefits for host countries. For some, they represent an opportunity for economic development for countries hitherto ignored by foreign investors and neglected by their leaders. These land "investments" have the potential to improve agricultural productivity and raise yields, as well as create jobs, transfer technology and develop infrastructure (FAO, 2009a). Some believe that foreign direct investment in agriculture is not only a vehicle of opportunities and sustainable development, but will also result in a greater food supply (World Bank, 2010). The development of the land, and consequently of agricultural production, would have a direct and positive impact on food security (Bell, 2009: 1).

Critics (Matondi et al., 2011; Cotula et al., 2009; GRAIN 2009a) identify land grabbing as a new form of colonialism. According to this premise, the massive purchase of land in developing countries by rich and emerging countries regenerates a neocolonial dynamic (Leahy, 2009) where the takeover of territory - and consequently soil, water and resources - challenge food sovereignty and democratic access to resources (Desmarais, 2008). In addition, its opponents can not ignore the potential impacts on the means and conditions of local communities, the environment, ecosystems.

\subsubsection{Conceptualizing Food security concept}

According to the FAO Committee on Food Security (CFS):

"Food security [...] exists when all people have, at all times, physical, social and economic access to sufficient, safe and nutritious food to meet their energy needs and dietary preferences for a healthy life." and active ". This definition identifies four essential dimensions that constitute food security: availability, accessibility, stability and utility / quality.

\section{- Availability based food security concept}

Availability is about the availability of sufficient food in all parts of the national territory, regardless of where the food comes from. It is the result of several factors, including production (local and national), marketing, processing, and foreign trade (imports). Availability assumes a physical existence of food products in sufficient quantity to ensure the food security of populations. For the purposes of our analysis, we will retain here that the land plays a key role in food production especially for households with insufficient or no income (income which is crucial for the accessibility dimension).

\section{- Accessibility based food security concept}

The "accessibility" dimension of food security implies access to the resources (natural or monetary) needed to produce or acquire the nutrients needed for a nutritious diet. Access to food depends on a number of conditions that are: the food market, the incomes of the population, the extended rights that different individuals may have, and the safety nets 18 in place to assist those who do not have the means to access food.

\section{- Stability based food security concept}

Stability implies that access to food is not interrupted or jeopardized by any natural or economic shock. It aims for permanent availability and access to food, thus covering the first two dimensions of food security. At this level too, we note that deprivation of access to land has a direct consequence on the stability of production at the local level, hence on availability and access.

\section{- Quality based food security concept}

And the last dimension, the quality, aims at a satisfactory use of food that is not threatened by health problems. In other words, the food available must be clean and healthy so as not to be a source of disease. The issue of quality includes the non-food dimension of food security, that is, the conditions that make feeding meet food needs, through its physiological use. Factors contributing to good food quality are: water and sanitation, disease prevention and management, standards and hygiene, and nutritional balance. 
As a result of this analysis of the four dimensions of food security, we can note that it refers to the right to food and its realization reflects the effectiveness of this right in all countries.

The right to food being defined as "the right to have regular, permanent and free access, either directly or by means of monetary purchases, to food that is quantitatively and qualitatively adequate and sufficient, corresponding to the cultural traditions of the people from which the consumer is born, and which ensures a psychic and physical life, individual and collective, free from anxiety, satisfying and dignified".

\subsection{Food security Conceptual Framework}

Most of the reviews literature on food security concept has recognized the development of the conpt in their work. They have conceptualized the concept into different dimensions which are related to the development of the concept. For FAO (2006), food security is conceptualized in four dimensions: availability, accessibility, stability and utilization.

Tweeten (1999) gives three dimensions: availability, accessibility and utilization. And Maxwell and Weibe (1998) describe the concept through three dimensions: sufficiency, sustainability and vulnerability.

Table 3. Food Security Conceptual Framework based on Food Security concept

\begin{tabular}{|c|c|c|c|c|}
\hline & $\begin{array}{l}\text { Availability based } \\
\text { food security concept }\end{array}$ & $\begin{array}{l}\text { Accessibility based food } \\
\text { security concept }\end{array}$ & $\begin{array}{l}\text { Quality based food } \\
\text { security concept }\end{array}$ & $\begin{array}{l}\text { Stability based food security } \\
\text { concept }\end{array}$ \\
\hline $\begin{array}{l}\text { Level of } \\
\text { analysis }\end{array}$ & National and global & $\begin{array}{l}\text { Household and } \\
\text { individual }\end{array}$ & National and global & National and global \\
\hline Main focus & $\begin{array}{l}\text { Sufficiency of food } \\
\text { supply }\end{array}$ & Entitlements & Quality of food & Sustainability of food \\
\hline $\begin{array}{l}\text { Concerning } \\
\text { issues }\end{array}$ & $\begin{array}{c}\text { Efficiency and } \\
\text { cost effectiveness } \\
\text { New food crops } \\
\text { Available of food } \\
\text { through food } \\
\text { production, food } \\
\text { trade and food } \\
\text { transfer }\end{array}$ & $\begin{array}{ll}> & \text { Endowment factors } \\
> & \text { Exchange } \\
> & \text { Economic } \\
\text { endowment } & > \\
\text { Poverty and } \\
\text { income } \\
> & \text { Infrastructures } \\
> & \text { Job creation }\end{array}$ & $\begin{array}{l}\quad \begin{array}{l}\text { Agricultural skills } \\
\text { and technologies }\end{array} \\
\text { Nutritional quality } \\
\text { and use }\end{array}$ & $\begin{array}{l}>\quad \begin{array}{l}\text { Equitable redistribution of } \\
\text { resources }\end{array} \\
>\quad \text { Sustainable management }\end{array}$ \\
\hline
\end{tabular}

Source: Author's calculations.

\subsection{Link between land grabbing and food security}

Following the analysis of the two concepts, we note a very close link between land grabbing and food security. Indeed, land as a factor of production is an essential element of the lives of rural families, and as such directly impacts the four dimensions of food security for these families, namely: availability, access and stability (Mohamed C., 2017). In terms of illustration, the lands occupied and exploited by families produce foodstuffs (cereals, citrus fruits, fruits, ...) that constitute the basis of food. Also, this production through marketing provides income which in turn will allow access to other types of goods and services that are not available at their level.

As a result, the four dimensions mentioned above of food security are confused: accessibility that is physical or material because the available food is produced by those who use it. The stability of this production varies because the families can no longer reach the new season with the production with the production of that passed and necessarily need support during the lean season to feed.

Thus, the four dimensions merge: access is physical or material because the available power is produced by those who use it. The stability of this access varies, however, because not all families can reach a new season with the production of the past, and need support during the lean season for food.

And to finish the utility / quality of production, because with the phenomenon of land grabbing, we are confronted with the disappearance of peasant agriculture, the degradation of the environment and the emergence of products with a high rate of pesticides. The scarcity of products will translate the lack of food, energy and nutritional needs of populations affected by land grabbing. For example, an unbalanced diet and precarious food hygiene are all factors limiting the required intake of nutritional requirements. 


\section{Land grabbing and food insecurity in Africa}

From 2007 to 2010 more than 1,000 land deals were completed in Sub-Saharan Africa, equivalent to Kenya and Cameroon (FAO, 2010). The most targeted countries include Ethiopia, Tanzania, Sudan, the Democratic Republic of Congo and Madagascar. Beyond being the main destination of land grabbing on a global scale, Africa is also the continent most affected by the problems of food insecurity. According to the FAO (2010, more than 240 million people, or $30 \%$ of the population is undernourished in Sub-Saharan Africa, more serious in countries like Burundi, Eritrea and the Democratic Republic of Congo, hunger nearly half of the population in Kenya, more than 4.1 million people face extreme food insecurity, while 7.6 million Kenyans are unable to meet their daily food needs (FAO, 2010). In addition to recurrent famines, high population growth, droughts and conflicts put additional pressure on land and natural resources.

According to Ziegler (2007), there are more than 800 million undernourished people in Sub-Saharan Africa, mainly those living in rural areas, dependent on agriculture for their livelihood and spending the majority of their income. to feed themselves, who will be most affected by this transformation of the global agri-food system. According to FAO and the World Bank, land acquisition for agricultural production favors the economic and rural development of poor countries (cited in GRAIN, 2010). For its critics, land grabbing in Sub-Saharan Africa is a form of neo-colonialism in which poor states produce food for the rich at the expense of their own undernourished population (Borger, 2008). Oxfam (2012) reports that while these investments are normally beneficial for the economic development and productivity of developing countries (usually based on short or medium term economic rationing), land acquisitions threaten the welfare of 80 million people peasants, the majority of whom are in Sub-Saharan Africa. In light of this situation, it is necessary to question the consequences: how does land grabbing in Africa affect food security? How will land grabbing and the introduction of new crops affect food availability, accessibility, quality, utility and stability? Is land grabbing a factor of food insecurity on the continent?

In our research, we noted that the issues and impacts of land grabbing on food security are multiple. For some, it has benefits, while others are clearly threats to food security. In order to explain why and how land grabbing can potentially hinder or promote food security of countries in Africa, we will support the different impacts in light of the four dimensions of the concept of food security.

\section{Impacts of land grabbing on food security}

\subsection{Impacts on food availability}

Food availability is based on the supply (or stock) of food at the national level. According to the World Bank (2010), land acquisition and investment in the agri-food sector help improve agricultural productivity and thereby increase the food supply of "host" countries Potvin, (2013). In order to assess the potential impacts on the food stock, there is a need to look at technology transfers, exports and the conversion of food crops.

\section{- Technology transfer}

Capital transfers, especially material and technological, materialize the promise of governments to stimulate rural development, in particular by increasing domestic productivity and improving the quality of agricultural products (Hallam, 2009: 33). In theory, countries receiving foreign direct investment tend to benefit from technological improvements, increased product quality and food quality standards. However, Hallam (2009: 33) also notes that the potential improvementfor food production due to technology transfer is uncertain if technologies are not shared with local producers. To date, few or no provisions to this effect are included in acquisition contracts, which in no way obliges foreign companies or governments to share their human or technological capital with rural communities. Cotula (2011:26) notes that the terms of contracts are generally vague as to the legal obligations of investors on the duration, quality and nature of their social and environmental commitments.

\section{- Production for export purposes}

All of the land grabbed is for food and agrofuel production that will be exported (Hallam, 2009: 27). As a result, the investment does not lead to any significant positive effects on the food balance of the "host" country. For example, in Madagascar, the entire production of the famous Deawo case was supposed to be exported to South Korea (Hall, 2011: 201). Some argue that these exports do not affect the food security of local 
populations because without these investments, mega food and agrofuel crops would not be produced anyway (World Bank, 2010).

According to this thesis, land grabbing and food production for export purposes or for agrofuel production does not influence the current state of undernourishment in Africa. By contrast, the majority of countries that have surrendered their land are large food importers or receive international assistance. In the case of Ethiopia, it receives \$ 116 million annually in food aid from the World Food Program (Prague Global Policy Institute, 2012: 9). At the same time, Saudi Arabia is paying Addis Ababa, Ethiopia, more than $\$ 100$ million annually to produce its grain on Ethiopian farms for export and consumption in Saudi Arabia (Kugelman, 2009: 10).

\section{- Conversion of local agriculture}

Foreign investment in African agricultural land does not necessarily lead to an increase in the domestic food supply since not all investments are dedicated to food production (Potvin, 2013). Indeed, while food security strategies are a key driver of land grabbing, many land acquisitions are motivated by increasing global demand for biofuel (Cotula et al., 2009: 54). The increasing use of food crops and feedstocks for fuel has rapidly (and will continue to) alter the fundamental economic dynamics that have governed global agricultural markets to date (Elobeid and Hart, 2007).

Crops for energy production compete with local food crops in a number of ways. The abandonment of local crops for biofuels has two main consequences for food availability in Africa.

On the one hand, if land, water and other natural resources are used to produce biofuels rather than food, food availability declines. In addition, if the use of food crops such as corn and soybeans for biofuels increases, then the price of these commodities increases, making these products less accessible for the poor, as was the case in 2008. D ' On the other hand, since the acquisition of land stimulates the economy of the "host" countries, the latter have more resources to, among other things, import food products and ensure domestic availability. Several countries in the region, including Sudan, are important food importers (Cotula et al., 2009: 43). Foreign investments in the agricultural sector, if carried out fairly and ecologically, can increase the stock of food in their domestic market and thereby contribute to ensuring the food security of the population (Shepard and Mittal, 2010).

\subsection{Impacts on food accessibility}

One of the pillars of food security is the ability of households and individuals to physically and economically access food of high quality and respectful of local food traditions. Whatever one says, land grabbing disrupts social, economic and environmental dynamics, and involves economic and physical accessibility to factors of production.

In this context, accessibility becomes dependent on the local food stock from land cultivated by small producers. Thus, physical accessibility is impacted in two ways. First, land withdrawal, which leads to stock reduction or disruption, has a direct effect on physical access that becomes difficult or impossible, resulting in food insecurity for producers and their families.

\section{Foreign Direct Investment in Agribusiness and its Macroeconomic Impacts}

One of the major problems facing the African continent is the low rate of public and private investment in the agricultural sector, which has contributed in recent years to a serious impact on the agricultural productivity of the sector. According to World Bank (2010:7) studies, investments in agricultural land generally stimulate competition in the domestic market, which can stabilize agricultural market prices and encourage more trade both in production and marketing. Thus, better market conditions, for example foreign products sold at local market prices, encourage domestic consumption by ensuring greater economic access to food (Hallam, 2009: 32). In addition, the inflow of foreign capital induced by land acquisition can stimulate the national and local economy, which influences local income standards (OFCE, 2011:225). Supporting this premise, agribusiness investments in theory stimulate (in a closed and perfect system) the affordability of food (Hallam, 2009). However, in a real economic system, many variables can influence the macroeconomic impacts expected by land grabbing. Thus, in an open and imperfect system, it is uncertain that foreign land investors will sell their food product on the African domestic market at the same price as local products. In reality, foreign direct investment in agrarian land largely depends on the vagaries of the economic market, which can constrain economic access to food (Potvin, 2013). 


\section{- Job creation}

The acquisition of land for agricultural and agrofuel purposes is likely to create employment (Zoomers 2010, Cotula et al., 2009: 81). Foreign investment in agricultural land, if it creates local employment, can allow individuals hired by the investor to directly increase their income, which then provides them with the financial means to buy food market (Smaller and Mann, 2009). However, for Matondi (2011: 152), the premise that the income generated by the wage employment of premises hired on foreign commercial farms outweighs the potential benefits of individual food production, such as family or subsistence farming, is wrong. As illustrated by a number of cases in Ethiopia (Beyene, 2011: 91-92), grabbed land, including land owned by small producers, is now grown by foreign companies for food or agrofuel production. The products are then exported to foreign countries, and rarely marketed in local markets. In addition to generating a decrease in the domestic food stock, this has the effect of distorting the local market, undermining the ability of small African producers to compete (OECD, 2008: 39). In other words, the wage offered to local workers on foreign farms is generally attractive by local standards. Many locals, men and women, are then tempted to abandon family farming to become employees. However, as previously explained, the injection of foreign capital into the local economy accentuates the domestic inflation, which is driven by the rise in agricultural and energy commodities that will likely continue in the coming years (OFCE, $2011: 213$ ).

Despite a better salary, such a scenario clearly limits the purchasing power of households and constrains their ability to access food economically. Significant inflation in Sub-Saharan Africa would lead to an increase in land value, and consequently reduce the ability of households to own property (OFCE, 2011). The number of "landless" would then increase, also contributing to household food insecurity at all levels (availability, accessibility, quality and stability), in addition to fragmenting communities and families (Potvin, 2013). .

The experience in Ethiopia (Beyene, 2011) demonstrates the contradictions regarding job opportunities made by foreign investors. For Vidal (2010), the portrait is eloquent: millions of tomatoes, peppers and other vegetables grow in rows where conditions are controlled by computers; Spanish engineers built the metal structures; Dutch technologists minimize the use of water with two wells; and 1,000 women pick and pack 50 tons of food a day. In less than 24 hours, the production was transported more than $300 \mathrm{~km}$ to Addis Ababa and flies more than 1,600 km to restaurants in Dubai and major cities in the Middle East. While 1,000 women have been hired, tens of thousands of peasant families are displaced from their lands and livelihoods.

\section{- Biofuel and its impact on prices}

The overall food challenge is magnified by adding the impacts of agrofuel production to the equation. While food security in this geopolitical area is also dependent on regional conflicts, weak governance structures and lack of local leadership, the multiplication of land conversions for monoculture production will only exacerbate the situation (FAO, 2010 ).

According to the study by GovindaTimilsina and Ashish Shrestha (2010: 37), the increase in global agrofuel production puts real pressure on food prices and diverts agricultural crops for human consumption from food. fuel production. Indeed, the majority of crops used in ethanol production - corn, soybeans and sugar cane are also staple foods in Sub-Saharan Africa. As a result, exploiting these crops for biofuel production will necessarily increase food prices and hurt poor households. In the same vein, Eide (2008: 11-12) believes that increasing agrofuel production with raw materials stimulates global competition for arable land suitable for food production. Any conversion of land for biofuel production to the detriment of food production will inevitably affect food prices, as both sectors compete for the same resources.

For Matondi and Mutopo (2011: 81), the conclusion is clear: biofuel production contributes to food insecurity in Sub-Saharan Africa. In fact, only three countries, Burundi, Uganda and Bangladesh, have enough land to produce agrofuel without negatively affecting domestic food production (Giampietro et al., 1997). According to the Agricultural Science and Technology Council (2006), the overall expansion of agrofuel production for maize, oilseed and sugar cane crops will have negative impacts on the region's food security.

The price of these goods will be determined more by the market value of raw materials for biofuel than by the importance attached to human nutrition essential to life. With the price of oil going up, small producers in the world's biofuel production countries, particularly in Sub-Saharan Africa, are now being encouraged by their government to produce not just food crops, but rather crops. for the production of biofuel. In the medium term, these same small producers will pay the price; basic food products will be more expensive, while the global 
food supply will decline (Matondi and Mutopo, 2001: 81). For example, a poor household in Tanzania spends five times more on buying maize than a wealthy household (World Bank, 1993). While the cost of food accounts for 70 to 80 percent of a household's spending in rural Tanzania, rising commodity prices will force many families to opt for cheaper and less nutritious foods; such a situation will increase health risks and increase malnutrition rates.

In light of this context, current analyzes lead us to believe that the conversion of agricultural production to food or agrofuel monoculture will in the medium and long term have negative impacts on food security and exacerbate poverty and hunger in Sub-Saharan Africa.

\section{- Physical accessibility}

\section{The displacement of the population}

Land in Sub-Saharan Africa sold or leased to foreign investors is often described as "available" or "insufficiently productive" (Cotula et al., 2009: 62). On the other hand, the majority of "grabbed" fertile lands are actually already used by locals.

According to Daniel and Mittal (2009), the acquisition of large areas of land has the potential to increase the number of landless rural people since the majority of the population in the region lives in rural areas. To make room for the broad cultures of foreign companies or governments, whole communities are forced to leave their land; small producers are left without production factors. The displacement of the population, by displacing rural communities from their means of production, generates greater poverty and consequently decreases their economic accessibility to food (Cotula et al., 2009). In addition, forced migration decreases or even completely eliminates physical accessibility. Since the majority of rural households in Sub-Saharan Africa are subsistence farmers, removing access to and control of land limits the physical accessibility of households to natural resources, including drinking water, which they have need to support themselves (Haralambous et al., 2009). Moving small farmers from the land they depend on to feed and survive will only worsen the situation of the 1.8 billion people already marginalized (Spieldoch and Murphy, 2009: 46).

For example, land grabbing has displaced thousands of communities, particularly in Tanzania, Ethiopia, Mozambique and Zambia. For example, in Tanzania, a land contract signed by the government and leasing the US company AgriSol Energy over 800,000 hectares of land (at \$ 0.25 / acre) would have displaced about 160,000 internal refugees (Oakland Institute, 2011b). While the magnitude of population displacement differs from one country to another, the consequences are relatively similar. The land grabbed usually gives way to large-scale agricultural production. Wolde-Georgis and Glantz (2008) argue that this type of agricultural development is not dependent on responsible rural and ecological development or local food security. These investments led to the exile of hundreds of thousands of Africans, now deprived of their ancestral lands.

In all cases, women and indigenous groups are particularly vulnerable. According to the United Nations Permanent Forum on Indigenous Issues, the acquisition of land for biofuel production only endangers the rights of access to land for more than 60 million indigenous people worldwide (cited in Daniel and Mittal, 2009: 12). At present, it remains difficult to accurately assess the number of IDPs specifically due to land grabbing in Sub-Saharan Africa, as other factors push communities to migrate: conflict, nomadic groups, droughts and floods are all factors that cause people in this region to move. - Agrarian Reforms and Food Security The literature on agrarian reforms and its links to food security is plentiful and rich. According to Maxwell and Weibe (1998: 2), securing land tenure for local users increases agricultural productivity and the food supply, which together helps to increase local food security. According to the authors, land ownership, in addition to providing access to land and resources, generally facilitates access to credit, which allows small producers to obtain tools, seeds or others to boost their income. agricultural production. Following this logic, blocking agrarian reform in "host" countries is also an obstacle to achieving food security. Daniel and Mittal (2009) point out that efforts to advance agrarian reforms in several Sub-Saharan African countries are currently threatened by land grabbing. Spieldoch and Murphy (2009: 45) share this view. According to them, land grabbing has slowed land reform efforts in recent years, undermining efforts to improve domestic food security (see also Hallam, 2009: 34).

For example, progress in implementing agrarian reform in Tanzania, Kenya and Zimbabwe has been made in recent years, but has recently been hampered by foreign investors in the agricultural sector (Daniel and Mittal, 2009). This situation is not foreign, although not well documented, for other countries in the region. 


\section{- Infrastructures}

Foreign actors active in land grabbing in Sub-Saharan Africa often have to build infrastructure such as roads and harbors to transport their commodities. This is particularly the case in remote areas where infrastructure is weak or simply non-existent. For Meinzen-Dick and Markelova (2009: 72), infrastructure construction benefits not only foreign companies or governments, but also local people. For example, remote communities in South Sudan now have access to local markets through the construction of secondary roads (Oalkland Institute, 2011). The ability to physically travel to nearby village markets and to buy or sell food is a symbolic illustration of the physical accessibility essential to food security.

However, few investment projects have met their infrastructure promises. In the majority of cases, transport infrastructure is slow to emerge. For example, the Qatari government has promised to offer financial loans to build a new port in Kenya in exchange for leasing large areas of land (Cotula et al., 2009: 82). To date, the work has not started yet. In other cases, infrastructure poses social and environmental problems. This is particularly the situation in Mali. In 2008, the Malian government, under the "Rice Initiative" policy aimed at stabilizing food prices and restoring food self-sufficiency in the country, donated more than 100,000 hectares for 50 years to Malibya, a subsidiary of Libya Africa Investment Portofolio. The company was mandated to produce hybrid rice and grow the tomato, in addition to building one of the largest irrigation canal in Africa and a 40-kilometer road near the site.

However, the construction of the irrigation canal and the road have generated significant disturbances in the Kolongo region located 637 kilometers from the capital Bamako. Houses have been razed, gardens ravaged by bulldozers and fields for livestock occupied by machinery. Today, the canal divides the villages. The Oakland Institute (2011c) reports that of the 150 households affected by the first phase of construction, only 60 would have been compensated. While local communities in Kolongo are losing their lands and livelihoods, no publicly available report indicates how many people are employed at Malibya, nor how many are hired. In short, the case of Malibya in Mali illustrates how transport infrastructure can, on the contrary, hamper market supply and damage the physical accessibility of food while dismantling families and local communities.

\subsection{Impacts on utility and food quality}

Land acquisition and development can, over the long term, transform the fragile environmental balance in a number of ways. Environmental impacts will not only be reflected in soil, water and air degradation, but also in nutritional quality and use. Climate change and environmental impacts on food quality By 2020, an estimated 75 to 250 million additional people in Sub-Saharan Africa will have their livelihoods and food security compromised by environmental change, including water scarcity (UNDP, 2007: 99). Droughts, floods, desertification, rising temperatures and sea levels will reduce agricultural production by $50 \%$ by 2020 , and net revenues from agricultural production by $90 \%$ by 2100 (IPPC, 2007: 435). Climate change will not only exacerbate land degradation and water scarcity (Cotula et al., 2009: 53), but also threaten crops and reduce productivity to even lower levels. Land grabbing is detrimental to the environment and biodiversity by promoting intensive monocultures based on the misuse of chemical fertilizers and pesticides. Heavy use of fertilizers and pesticides can seriously damage the quality of the soil and surrounding waters, and even make farmland completely unusable for years.Thus, the contamination of food products grown on contaminated soils decreases the "quality" of food consumed, and consequently hampers the food security of the populations concerned (TNI, 2013: 13). Acquired land converted to the production of monocultures of cereals, food, animal feed or agrofuel (mainly sugar cane, corn and soybeans for ethanol production) require huge amounts of water in more to require a stable supply, especially through large-scale irrigation (TNI, 2013: 18).

Water is also at the heart of the issues of land grabbing. For Meinzen-Dick and Makelova (2009: 74), the diversion, depletion and pollution of local water resources is a direct threat to a wide range of local livelihoods. Local people, cut off from access to water for their consumption and livestock, are becoming increasingly vulnerable to food insecurity. Local water sources such as streams, lakes, rivers and nearby wells polluted by chemical releases and residues illustrate how large-scale, unregulated agricultural operations affect, even destroyed, local ecosystems and the economy. local politics. For example, in the context of the Bagamoyo project in Tanzania, the Swedish food company SEKAB's agro-food investments in biofuel production led to deforestation in several areas, jeopardizing the region's biodiversity and the livelihoods of neighboring communities. (Havnevik and Haaland, 2011: 106). The clearing of large areas of land, and in some cases the complete deforestation of the land, to make way for mechanized monocultures and agriculture erodes soil in 
addition to using, and even exhausting, meager sources of water (TNI , 2013: 14). Land grabbing and water control will continue to exacerbate the situation if nothing is done to mitigate environmental and social impacts.

\section{- New food crops}

Finally, the introduction of plant species and foreign cereals including plantations of palm, jatrophas, eucalyptus, sugar cane, soybeans, rice or wheat (recurrent products in the majority of cases of land grabbing) is likely to disrupt local biodiversity and traditional dietary habits. It is enough to cite the case of Malibya to illustrate how the introduction of a "foreign" product can undermine food security and eco-social links in the Kolongo region. According to Lamine and Monjane (2009), hybrid rice grown by Malibya is an inappropriate variety for the local market and food customs where local varieties are preferred for their flavor and texture. The Oakland Institute (2011c) agrees that importing and cultivating non-adapted species and grains not only compromises biodiversity and local culture, but neglects traditional dietary habits. Food use and quality are then undermined and food security is at risk.

\subsection{Impacts on food stability}

As explained above, food stability assumes food availability and accessibility "at all times", that is, permanently. Thus, to know if land grabbing impacts the "stability" of food security, it is worth asking about its impacts over time. Land grabbing and the contracts that govern these land transactions are established over time. For the most part, land acquisitions are spread over long periods. To know whether land grabbing contributes to the "stability" of food security, it is important to consider the impact of land grabbing over time. While the consequences of this phenomenon for food security are not immediate, it is possible to identify the precursors that will determine the viability of these investments for food security in Sub-Saharan Africa.

Lester Brown (2011: 68) takes an optimistic look at the potential of agricultural development in Sub-Saharan Africa. First, considering the level of agricultural skills and technologies used by foreign companies, in most cases, high agricultural yields should be expected. According to Brown (2011), in Africa, simply applying soil fertilizers, mostly low in nutrients, will double or triple the current agricultural yield. Following this logic, land grabbing (with modern farming practices) can increase food productivity and, consequently, increase the supply of food. In the longer term, technology transfers will boost the productivity of traditional agriculture. Thus, the availability of food can be maintained over time as the food production generated by investments in agricultural land is offered in the domestic market, and not only exported abroad. In addition, long-term investments can secure local jobs and thus support the food accessibility and well-being of rural populations. However, to date, there is no evidence to suggest that the potential jobs generated by investments in African agricultural land will be more numerous, profitable, equitable and socially responsible for those that will be lost as a result of these same economic activities.

In an ideal scenario, the stability of the four dimensions studied, namely availability, accessibility and quality, lies in sustainable management and equitable redistribution of resources. However, several factors can hinder the stability of investments and their outputs. For example, some projects will simply be abandoned.

Others will see their plantations affected by diseases or insect infections while foreign cultures will be introduced into new environments (Brown, 2011: 69). The globalization of agriculture will inevitably lead to greater dissemination of nutritional practices and knowledge (Maxwell, 2001), but also the risk of marginalizing or even eliminating certain local food habits and know-how (quality and use). Thus, while some projects will significantly increase food production (availability), Brown argues that the benefits promised to local communities (accessibility) must be questioned. If all products, including machinery, fertilizers, pesticides and seeds, are imported from abroad and all production is exported abroad, this will not contribute to the domestic economy or supply. local food (Brown, 2011: 70). The complexity of the phenomenon, its comprehensiveness and its multiple expressions constitute a major challenge for the sustainability of food security in the future. At present, several authors (De Schutter 2010, Cotula et al., 2009, Matondi and Mutopo 2011, Hallam 2009, Brown 2011) believe that land grabbing in its contemporary form conditions necessary to achieve the four dimensions of food security.

\section{Recommendations}

Populations are generally the first victims of the economic, political, social and environmental impacts generated by land grabbing. Some of the most common impacts include: 
$>$ the decline of peasant and family farming, with a negative impact on direct agricultural employment and a risk of rural exodus. women are particularly affected;

$>$ disregard for land and property rights that may lead to conflict and / or endangerment of vulnerable populations;

$>$ increasing land prices and land access difficulties for national farmers;

$>$ the deterioration of the food security of the local populations and the host country;

$>$ the degradation of the environment, with increased risks of deforestation, destruction of ecosystems, overexploitation of water resources, and massive use of chemical fertilizers and to remedy this phenomenon of massive land acquisition, it is necessary to:

$>$ develop land policies based on international human rights law and guiding principles for large-scale land investments and an investment code.

$>$ states must elaborate and reform land policies and negotiate contracts in a participatory way by integrating local populations and civil society organizations.

$>$ create space for public debate and support policy reform to foster positive consequences (eg with better local participation and public oversight of negotiations);

$>$ considering asymmetries of power in contract negotiations, strengthen the host government's negotiating capacity and the monitoring capacity of civil society;

$>$ support efforts to secure local land rights and support local groups in their negotiations with the government and investors;

$>$ share lessons learned from international experience, for example in addressing issues related to food security, balancing small- and large-scale agriculture, formulating contracts or fairness of farm plans;

$>$ examine the lending terms of government development funds available to private sector investors, to guide lending towards better land acquisition practice;

$>$ ensure that international rules provide strong guarantees and are supported by effective monitoring and enforcement.

\section{Conclusion}

To conclude this paper, we discussed how the phenomenon of land grabbing affects food security in Africa. In light of the four dimensions of food security, we have identified the various positive and negative effects of this phenomenon.

First, land grabbing on the continent, through foreign direct investment, capital transfers, technology and job creation, can contribute to increasing the individual income and living standards of the targeted populations and thus promote food security.

Although many authors in the literature advocate for this phenomenon by touting the potential benefits to host countries, the controversy remains because of the direct and potential risks to food security.

Secondly, following the logic of the analyzes carried out above, we have noted that the phenomenon of land grabbing contributes to exacerbate the social, environmental, political and economic pressures on the lived experience of the local populations. The high demand for food and biofuel, population pressure and climate change are factors contributing to food insecurity on the continent.

However, in order to remedy this, we have proposed recommendations to counteract the impact of land grabbing on food security and people's way of life. We can mention the development of land policies based on international human rights texts and guidelines on large-scale land investments and an investment code, taking into account family farming and others.

\section{References}

1. Ashley, C., et Maxwell, S. (2001). Rethinking Rural Development, Development Policy Review, 19(4), 395-425. DOI: https://doi.org/10.1111/1467-7679.00141.

2. Banque Mondiale (2007). World Development Report 2008: Agriculture for Development, Washington DC: Banque Mondiale. https://siteresources.worldbank.org/INTWDR2008/Resources/WDR_00_book.pdf

3. Banque Mondiale (2010). Rising Global Interest in Farmland: Can it Yield Sustainable and Equitable Results?Washington DC: Banque Mondiale. 
http://documents.banquemondiale.org/curated/fr/998581468184149953/Rising-global-interest-in-farmlandcan-it-yield-sustainable-and-equitable-benefits

4. Banque Mondiale (2010). Principles for Responsible Agricultural Investment that Respects Rights, Livelihoods and Resources, Washington, DC: Banque Mondiale. https://siteresources.worldbank.org/INTARD/2145741111138388661/22453321/Principles Extended.pdf

5. Banque Mondiale (2013a). Agriculture and Development: Regions. https://www.worldbank.org/en/topic/agriculture

6. Bernstein, H., Crow, B., Johnson, H. (1992). Rural Livelihoods: Crisis and Responses, Oxford University Press, Oxford. http://oro.open.ac.uk/11430/

7. Berry, S. (1989). Social Institutions and Access to Resources, Africa, 59(1), 41-55. DOI: https://doi.org/10.2307/1160762.

8. Berthelot, J. (2008). The ttrue of the fae in soaring world agricultural prices. https://www.cetim.ch/wpcontent/uploads/berthelot-mai-2008-ang.pdf

9. Beyene, A. (2011). Smallholder-led Transformation towards Biofuel Production in Ethiopia. In Matondi, P.B., Havnevik, K. et Beyene, A. Biofuels, land grabbing and food security in Africa, The Nordic Africa Institute : Zed Books, London. https://www.zedbooks.net/shop/book/biofuels-land-grabbing-and-food-security-inafrical

10. Borger, J. (2008). Rich Countries Launch Great Land Grab to Safeguard Food Supply, The Guardian. https://www.theguardian.com/environment/2008/nov/22/food-biofuels-land-grab

11. Borras, S. et Franco, J. (2010). Towards a broader perspective of the politics of global land grab policy: rethining land issues, reshaping the resistance, La Haye, ICAS, Working Paper Series $\mathrm{n}^{\circ} 1$. https://www.tni.org/en/paper/towards-broader-view-politics-global-land-grabbing

12. Brown, L. (2011). The New Geopolitics of Food, Foreign Policy, 54-62. https://foreignpolicy.com/2011/04/25/the-new-geopolitics-of-food/

13. De Schutter, O. (2011a). How not to Think of Land-grabbing: Three Critiques of Large- scale Investments in Farmland, The Journal of Peasant Studies, 38(2), 249-279. DOI: https://doi.org/10.1080/03066150.2011.559008

14. De bailleul, G. (2009). Low hand on southern farmland Alternatives, 15(6).

15. Deininger, K., Byerlee, D., Lindsay, J., Norton, A., Selod, H. et Stickler, M. (2011).Rising global interest in farmland: Can it yield sustainable and equitable benefits? The World Bank, Washington D.C.: World Bank Publications. http://documents.worldbank.org/curated/en/998581468184149953/Rising-global-interest-infarmland-can-it-yield-sustainable-and-equitable-benefits

16. Desmarais, A. (2008). La Via Campesina: a peasant response to the food crisis. https://viacampesina.org/en/an-answer-to-the-global-food-crisis-peasants-and-small-farmers-can-feed-theworld/

17. FAO (2006). Food security, Guidance note, no2, June, Rome. http://www.fao.org/fileadmin/templates/faoitaly/documents/pdf/pdf_Food_Security_Cocept_Note.pdf

18. FAO (2009a). Foreign Direct Investment: Win-Win or Land Grab? Rome: FAO. http://www.fao.org/tempref/docrep/fao/meeting/018/k6358e.pdf

19. FAO, PAM (2009). State of food insecurity in the world: economic crisis, repercussions and education; Rome, FAO, http://www.fao.org/docrep/fao/012/i0876f.pdf

20. Fox, J. (1993).The Politics of Food in Mexico : State Power and Social Mobilization, Center for US-Mexican Studies.

https://www.researchgate.net/publication/237132534 The Politics of Food in Mexico State Power and Social_Mobilization

21. Friedland, W. H. (1994). The New Globalization: The Case of Fresh Produce. In A. Bonanno, L. Busch, W. Friedland, L. Gouveia et E. Mingione, From Columbus to Cona-gra: The Globalization of Agriculture and Food, Lawrence, Kansas: University of Kansas Press, p. 210-231. https://www.amazon.com/ColumbusConAgra-Globalization-Agriculture-Food/dp/0700606610

22. Friedmann, H. and P. McMichael (1989). Agriculture and the State System: The Rise and Decline of National Agricultures, 1870 to the Present, Sociologia Ruralis, 29(2), 93-117. DOI: https://doi.org/10.1111/j.14679523.1989.tb00360.x

23. Friis, C. et Reenberg, A. (2010). Land Grab in Africa: Emerging Land System Drivers in a Teleconnected World, GLP Rapport n 1 , Copenhagen: GLP-IPO. https://wedocs.unep.org/handle/20.500.11822/19703 
24. GBN (2010). Land Grabbing for Biofuels hits Ghana, other African Countries. http://www.ghanabusinessnews.com/2010/08/30/land-grabbing-for-biofuels-hits-ghana-other-africancountries-report/

25. GRAIN (2008). Seized! The 2008 Land grab for Food and Financial Security, GRAIN Briefing, Octobre 2008. https://www.grain.org/article/entries/93-seized-the-2008-landgrab-for-food-and-financial-security

26. GRAIN (2009a). The New Farm Owners: Corporate Investors lead the Rush for Control over Overseas Farmland, Against the Grain, 10p. Disponible à : http://www.grain.org/article/entries/194-the-new-farmowners.

27. IFAD (2009). Sending Money Home to Africa. Remittance Markets, Enabling Environment and Prospects, Rome: IFAD. https://www.ifad.org/documents/38714170/40193590/Sending+Money+Home+to+Africa.pdf/90b3ec935ece-4b90-9e5c-2159ebebdad6

28. IFPRI (2009). Land Grabbing in Developing Countries: Risks and Opportunities, Policy Brief, no13. https://econpapers.repec.org/paper/fprpolbrf/13.htm

29. IFPRI (2012). The Challenge of Hunger: Ensuring Sustainable Food Security under Land, Water, and Energy Stresses, Global Hunger Index, 2012, IFPRI. Disponible à: http://www.ifpri.org/publication/2012-globalhunger-index.

30. ILC - International Land Coalition (2011), Land Rights and the Rush for the Land, Rapport de recherche, Cirad et ILC, 72 p. https://www.landcoalition.org/sites/default/files/documents/resources/ILC\%20GSR\%20report_ENG.pdf

31. Matondi, P. B. (2011). Agro-investments in Zimbabwe at a Time of Redistributive Land Reforms. In Matondi, P.B., Havnevik, K. et Beyene, A., Biofuels, land grabbing and food security in Africa, The Nordic Africa Institute: Zed Books, London. https://www.diva-portal.org/smash/get/diva2:387049/FULLTEXT01.pdf

32. Maxwell, Daniel and Keith Wiebe (1998). Land tenure and food security: a review of concepts, evidence and methods. https://ideas.repec.org/p/ags/uwltrp/12752.html

33. Tweeten, Luther (1999). The economics of global food security. Review of Agriculture Economics. https://www.jstor.org/stable/1349892

34. Oakland Institute (2011a). The Myth of Job Creation, Land Deal Brief, CA: The Oakland Institute. www.oaklandinstitute.org/sites/oaklandinstitute.org/files/OI brief myth job creation 0.pdf.

35. OFCE (2011). Emerging Countries: Capital Flows and Soaring Commodity Prices [Pays émergents: afflux de capitaux et envolée des prix des matières premières], Revue de l'OFCE, 2(117), 201-231. https://www.southcentre.int/wp-content/uploads/2013/05/RP37_Capital-Flows-to-developingcountries_EN.pdf

36. Oxfam (2008). Another Inconvenient Truth: How Biofuel Policies are Deepening Poverty and Accelerating Climate Change, Briefing Paper no114, Oxford: Oxfam GB. https://policypractice.oxfam.org.uk/publications/another-inconvenient-truth-how-biofuel-policies-are-deepeningpoverty-and-accel-114084

37. Polanyi, K. (1992). The Economy as Instituted Process, In Mark Granovetter and Richard Swedberg, The Sociology of Economic Life, Oxford, Westview Press, p. 29-51. https://www.worldcat.org/title/sociologyof-economic-life/oclc/470767250

38. Prague Global Policy Institute (2012). Land Grabs in Africa: A Threat to Food Security, Glopolis: Prague. http://glopolis.org/wp-content/uploads/soubory/land-grabs-in-africa.pdf

39. Potvin Valerie (2013). Land grabbing and its impacts on food security in sub-sahan Africa.

40. Programme alimentaire mondial (2012). Identifying Opportunities for Climate-smart Agriculture Investments in Africa, Programme Alimentaire mondial, Rome. http://www.fao.org/3/a-i2640e.pdf 